\title{
Detection of shoreline changes: a geospatial data analysis in Vung Tau City, Southern Vietnam
}

- Bui TrongVinh

- Ly Minh Hoang

Department of Earth Resources and Environment, Faculty of Geology and Petroleum Engineering, Ho Chi Minh city University of Technology, VNU-HCMC

(Manuscript Received on August $10^{\text {th }}$, 2015; Manuscript Revised on October $15^{\text {th }}$, 2015)

\section{ABSTRACT}

In recent years, beach and shoreline erosion has occurred increasingly around the world. Because of climate change and human activities, many beaches and shorelines have been eroded severely in Vietnam, especially in Vung Tau City. In order to understand and explain the reasons why Vung Tau beaches have been eroded, the author applied the Geographic
Information System (GIS) and Remote Sensing (RS) to analyze the movement of beach in the past and present. The results showed that Vung Tau city has witnessed a massive shoreline replacement including severe erosion and gradual accretionsince 1989. CuaLap river mouth features all-time biggest changes with more than 800 meter of retreating shoreline.

Keywords: beach erosion, shoreline erosion, accretion, GIS, RS, Vung Tau, Cua Lap, river mouth

\section{INTRODUCTION}

Coastal zone is considered asone of the most dynamic environments innature, morphological variations of shoreline are strongly influenced by natural conditions and anthropogenic interventions. These changes have different manifestations in both time and space. The most important aspect of managing coastal areas is identifying the location and change of shoreline over time. Nowadays, monitoring coastal dynamics isthoroughlysupported by rapid development of geospatial technology and Geographic Information System (GIS) whereas remote sensing is effectively used to define shoreline changes with admissible accuracy. In this paper, the authorsapplied geospatial technique to carry out quantitative analysis ofshoreline change evaluations in Vung Tau City.

Vung Tau City is located in the southern economic region of Vietnam (Figure 1). Since late 70s, Vung Tau has proven its fast-paced urbanization and industrialization due to the rising of petroleum industry, tourism, sand mining etc.Long stretches of white sand in Vung Tau city have been representedas the most popular recreational destination in Vietnam. Throughout these years, this city has witnessed amassive widespread of shoreline retreating phenomenon. As coastal population continues to grow and land properties are threatened by 
erosion, there is imperative need for precise information regarding past and present trends of shoreline movement.

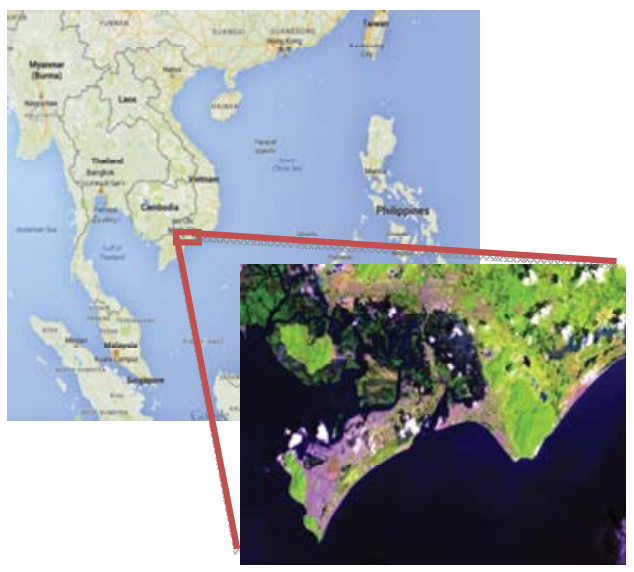

Figure 1. Research areas- Vung Tau City

\section{Methodology}

Shoreline change evaluations are based on comparing historical cartography, satellite data and topographic field surveys. Before GPS (GNSS) and satellite spectral sensors, the most commonly used resources of historical shoreline position were original cartography (Robert A. Morton et al., 2004). Ideally, the derivation of shoreline position from historical data sources involves verification and calibration using ground control points.In recent years, satellite data have been accessed and pre-processed easier as they can help or replace conventional survey for its repetitive and less costeffectiveness. The authors useda set of data that embody a group of Landsat archived from 1989 to 2015 and a 1968-cartography map listed in Table 1. After geo-referencing and preprocessing, band ratio of mid-infrared (band 5) and green (band 2) were used to analyze the terrestrial landforms and water boundary asEquation 1(Deguchi et al., 2005). Specifically, The former indicates positive value whereas the latter shows negative value, which decreases subjectivity in delineating shorelines.
Table 1. Landsat data archive using in this research

\begin{tabular}{|c|c|l|c|}
\hline Date acquired & Sensors & Satellite & Path/row \\
\hline $17-01-1989$ & MSS & Landsat 4 & $124 / 053$ \\
\hline $11-08-2000$ & ETM & Landsat 7 & $124 / 053$ \\
\hline $24-11-2006$ & TM & Landsat 5 & $124 / 053$ \\
\hline $18-12-2009$ & TM & Landsat 5 & $124 / 053$ \\
\hline $18-10-2014$ & OLI_TIRS & Landsat 8 & $124 / 053$ \\
\hline $21-03-2015$ & OLI_TIRS & Landsat 8 & $124 / 053$ \\
\hline
\end{tabular}

In addition, false color composite images were implemented for natural discrimination (by assigned $\mathrm{R}=\mathrm{SWIR}, \mathrm{G}=\mathrm{NIR}, \mathrm{B}=$ Band 2) between tidal flat/ deposition areas and erosion ones.

$$
\mathrm{TM}_{5-2}=\frac{\bar{\theta}_{5}-\bar{\theta}_{2}}{\bar{b}_{5}+\bar{\theta}_{2}} \mathrm{Eq}
$$

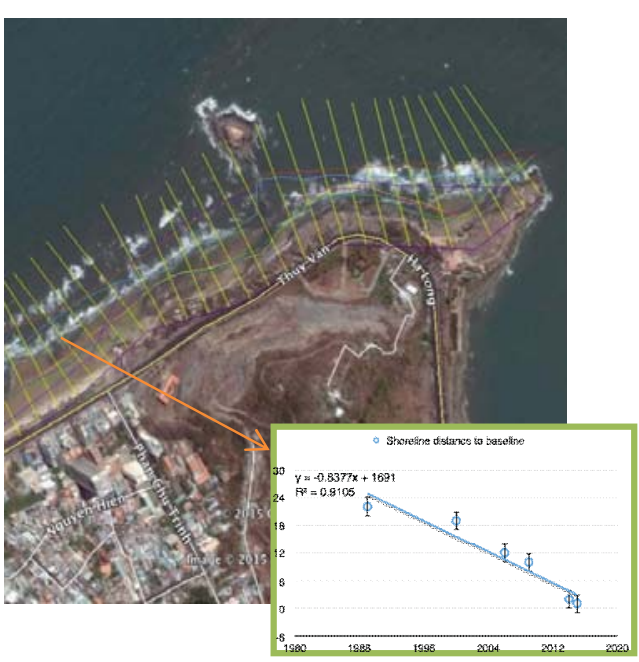

Figure 2. Shoreline and casted

In order to assess quantitative coastline changes, the authors also conducted a shoreline analysis using DSAS 4.3 (Digital Shoreline Analysis System). The application computes 
rate-of-changes statistics for a time series of shoreline vector data. Initially, The collected satellite data of Vung Tau city were preprocessed and exported to GIS application as GeoTiff extension. Subsequently, these images were digitalized and then becameinput for DSAS module.In the following step, a series of perpendicular transects was automatically casted to the shoreline in 10 meter and 50 meter interval, transects were also manually adjusted to ensure crossing all the shoreline.

Intersection points were used to detect the rate of erosion/deposition in this area (Figure 2). The DSAS application offers 5 modules namely shoreline change envelop (SCE), netshoreline movement (NSM), end point rate (EPR), linear regression and weighted linear regression (LR and WLR) (Thieler et al, 2009). The authors chose EPR and NSM to analyze Vung Tau shoreline data. NSM demonstrates the gap between the youngest and oldest shoreline while EPR represents the rate of changes by divide NSM for time gap. The complete process workflow is described in Figure 3.

Long-term shoreline changes in Vung Tau city

Between 1940 and 1950, erosion occurred in some coastal parts of Vietnam, though the rates of erosion were low. Since 1960, coastal erosion has been common in southern delta provinces as shoreline changes become more complicated, with many of them resulting in severe consequences(Tien et al., 2005). Vung Tau'sopen ocean coastline is characterized as the development of low foreshores and mainly composed of mud and clay which can be easily influenced by anthropogenic activity and natural impact (Cong et al, 2014).

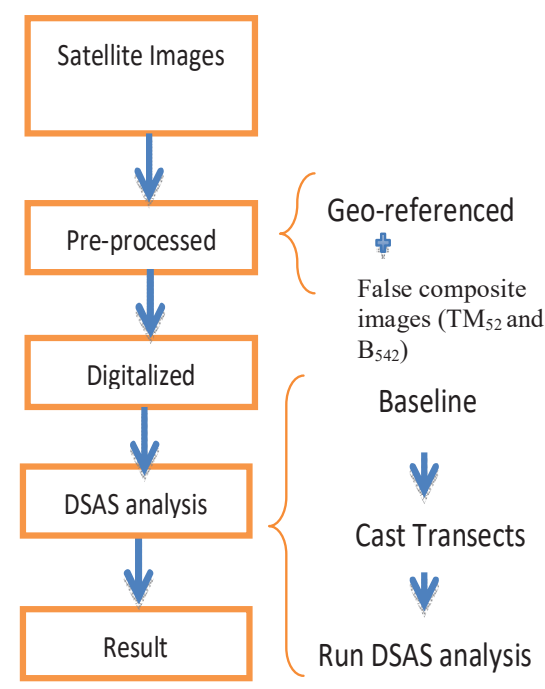

Results

Figure 3. Shoreline analysis workflow

Generally, shoreline changes are presented with an emphasis on shoreline erosion, because it is an important natural hazard along most of the part of Vung Tau's beach. The authors subdivided research area into three sectors including: A- Cua Lap river mouth, B- ParadiseThuyTien Beach and C- NghinhPhong cape. These sectors stand for unique morphological features in Vung Tau Beach involving river mouth, sandy beach and cape rock formationrespectively.Figure 4 illustrates longterm shoreline changesof Vung Tau city from 1989 to 2015 . In the 25-year period, land losses were primarily associated with erosion of sandy beaches, especially around river mouth (Cua Lap river mouth) whereas deposition was uncommon along the coast. 


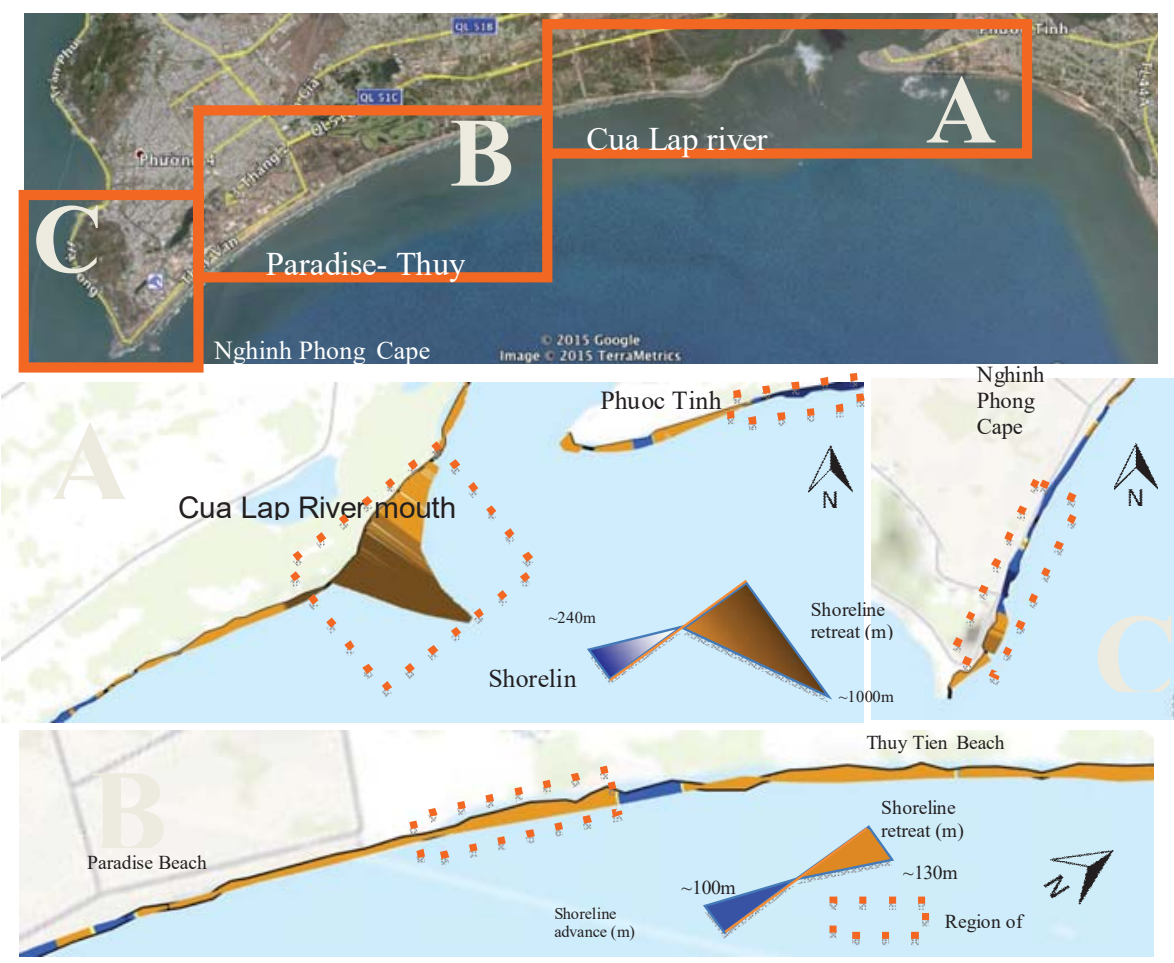

Figure 4. Shoreline changes map from 1989 to 2015

The littoral stretch close to Lap River is characterized by a catastrophic erosion phenomena (of more than -800-meter retreating shoreline). This trend has continued to affect larger area close to the river mouth. This case is reversed for PhuocTinh - Long Hai area, where accretion was dominant erosion (more than $+120 \mathrm{~m}$ comparing to the original 1989 shoreline). On the other hand, the retreating shoreline are observed in NghinhPhong cape (rock formation)with 154 meter of shoreline has been retreated backward, whereas adjacent shoreline in Thuy Van Beachfeaturea notable increase in accretion surfaces.

This case is also the fact that not all places along a shoreline are equally vulnerable. Jutting points of land, or headlands, are more actively under attack than recessed bays because wave energy is concentrated on these headlands by wave refraction, deflection of the waves around irregularities in the coastline (Carla W.Montgomery, et al 2011). Land loss is also observed in the coastal zone located between Paradise Beach and ThuyTien Beach, distance from a typically recent reference point to the old shoreline might appear from $20 \mathrm{~m}$ to $50 \mathrm{~m}$.

\section{Interpretation of analyzed data}

A long-term end-point-rate (EPR) analysis of shoreline changesreveals the predomination of erosion in this area. As can be seen in Figure 5 , moderate erosion rate $(0 \mathrm{~m} /$ year to $-4 \mathrm{~m} /$ year $)$ which make a contribution of 228 calculated transects appears to be the most likelihood level of retreating shoreline that happened in Vung Tau city. Specifically, severeerosion is observed with the maximum erosion rate of $-18.4 \mathrm{~m} /$ year 
where as deposition is noticed at the maximum rate of $14.53 \mathrm{~m} /$ year. From statistical point of view, the authors found that erosion in Vung Tau accounted for $74,71 \%$ of cumulativelyanalyzed transects, this incidental finding demonstrates an overall disequilibrium state of coastal morphological dynamics in 25year gap.

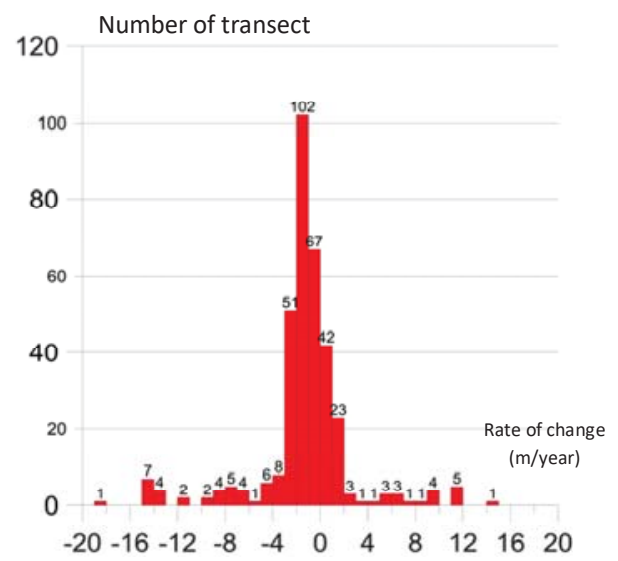

Figure 5. Histogram of shoreline EPR from 1989 to 2015

Table 2. Shoreline EPR in investigation

\begin{tabular}{|c|c|c|}
\hline $\begin{array}{c}\text { Period of } \\
\text { time }\end{array}$ & $\begin{array}{c}\text { Average } \\
\text { EPR(m/year) }\end{array}$ & $\begin{array}{c}\text { Maximum } \\
\left.\text { EPR(m/ } \mathbf{y}^{-1}\right)\end{array}$ \\
\hline $1989-2000$ & -3.089 & -25.68 \\
\hline $2000-2009$ & -1.717 & -18.68 \\
\hline $2009-2015$ & -1.201 & -23.34 \\
\hline
\end{tabular}

For the period 1989-2000, a comparison of shorelines features the dominance of serve erosion phenomena, quantifiable as $\sim 1,115,366 \mathrm{~m}^{2}$ eroding surfaces and $\sim 312,894$ of accreting surfaces (Figure 7 and Table 3), an average rate of change value of $-3.089 \mathrm{~m} \cdot \mathrm{y}^{-1}$. Human interventions were shown up intermittently between 1989 and 2000, as a result, the causes of erosion particularly came from natural conditions such as storm namely TESS and Linda.

Between 2000 and 2009, Vung Tau's shoreline was atemporal equilibrium between growing and lost surfaces $\left(-330,314 \mathrm{~m}^{2}\right.$ versus $\left.+444,891 \mathrm{~m}^{2}\right)$. Various coastal structureswere built at that time in order to protect the shoreline of PhuocTinh, Paradise and ThuyTien Beach Correspondingly,a sharp decrease of erosion had been observed throughout the beach

Table 3. Rate of surface changes $\left(\mathbf{m}^{2} \mathbf{y}^{-1}\right)$ in Vung Tau beach

\begin{tabular}{|c|c|c|c|c|}
\hline $\begin{array}{l}\text { Period of } \\
\text { time }\end{array}$ & $\begin{array}{c}\text { Erosion } \\
\text { Areas }\left(\mathrm{m}^{2}\right)\end{array}$ & $\begin{array}{c}\text { Accretion } \\
\text { Areas } \\
\left(\mathbf{m}^{2}\right)\end{array}$ & $\begin{array}{c}\text { Net } \\
\text { difference }\end{array}$ & $\begin{array}{c}\text { Rate of } \\
\text { changes } \\
\left(\mathrm{m}^{2} \mathrm{y}^{-1}\right)\end{array}$ \\
\hline $1989-2000$ & $1,115,366$ & 312,894 & $-802,472$ & $-72,925$ \\
\hline $2000-2009$ & 330,314 & 444,891 & $+114,577$ & $+12,730$ \\
\hline 2009-2015 & 359,664 & 209,223 & $-150,441$ & $-25,070$ \\
\hline
\end{tabular}

A comparisonbetween 2009 and 2015 reveals an entire reversal in the previous trend. The most vulnerable area was captured at Cua Lap (Figure 6) with maximum erosion rate of $23.34 \mathrm{~m} \cdot \mathrm{y}^{-1}$. Coastal displacement has been continuously happening along the shore where $25,070 \mathrm{~m}^{2}$ of land has been lost. The reason for thesephenomena is mainly caused by deterioration of existing dike system (which was built in 2004 and 2005) -Figure 6 (b).

The lack of sediment budget can also be explained by sand mining projects in other upstream provinces and offshore sand mining. Nowadays, coastal regions are now facing progressively extreme weather under climate change conditions such as storms, surges and sea level rise. Philip Schmidte-Thome (et al 2015) states that with high emission sea level rise scenario (A2, A1FI), the flooded area of Ba RiaVung Tau province is $5.9 \%$ which coastal city are the most vulnerable. 


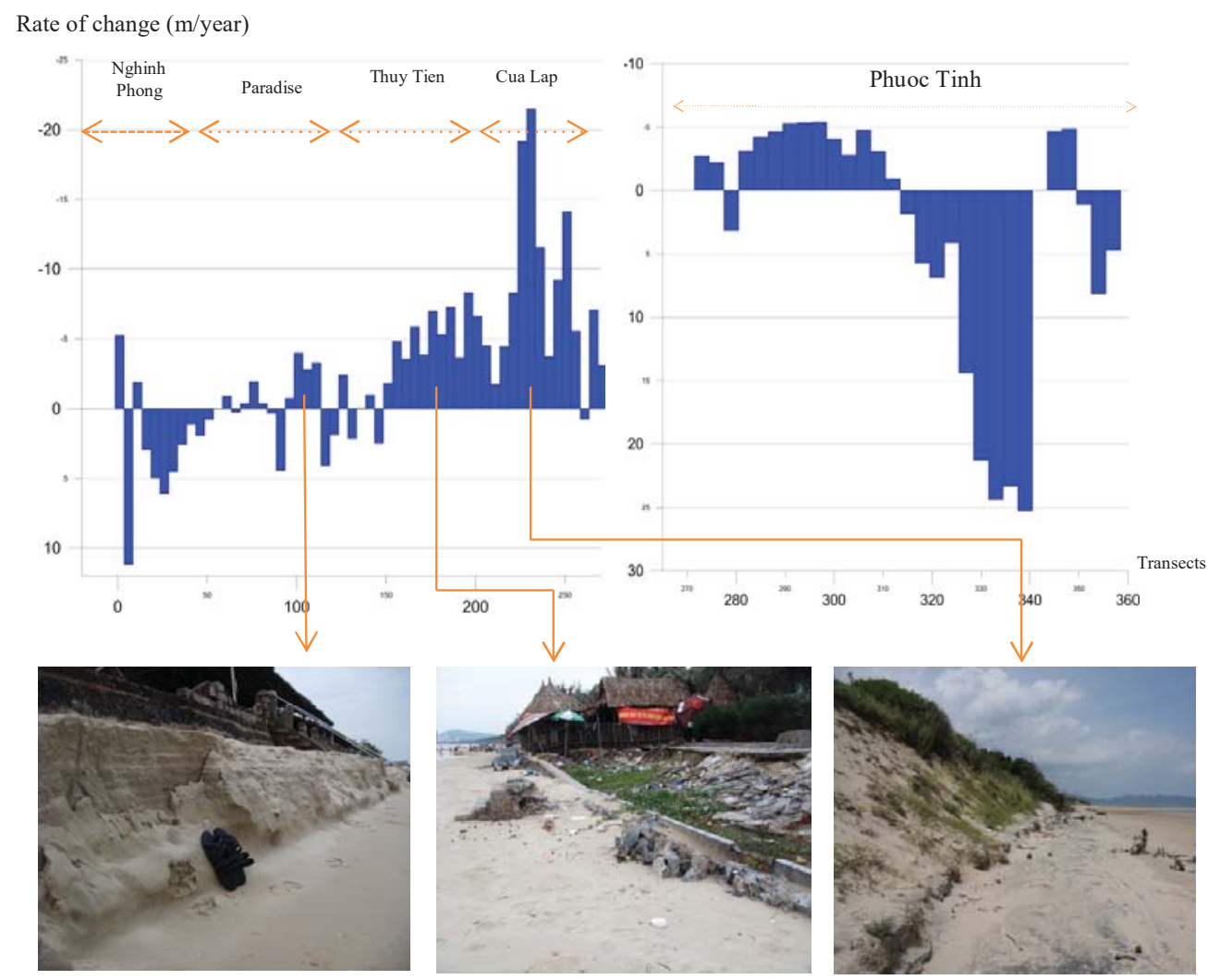

Figure 6. EPR of shoreline from 2009 to 2015 and photographs from Paradise beach, Thuy Tien beach and Cua Lap river mouth from bottom left 
- 1989-2000: TESS and Linda storm

- 2000-2009: Phuoc Tinh, Thuy Tien seawall, dike system

Durian storm (2006)

- 2009-2015: Parkhar storm (category 8)

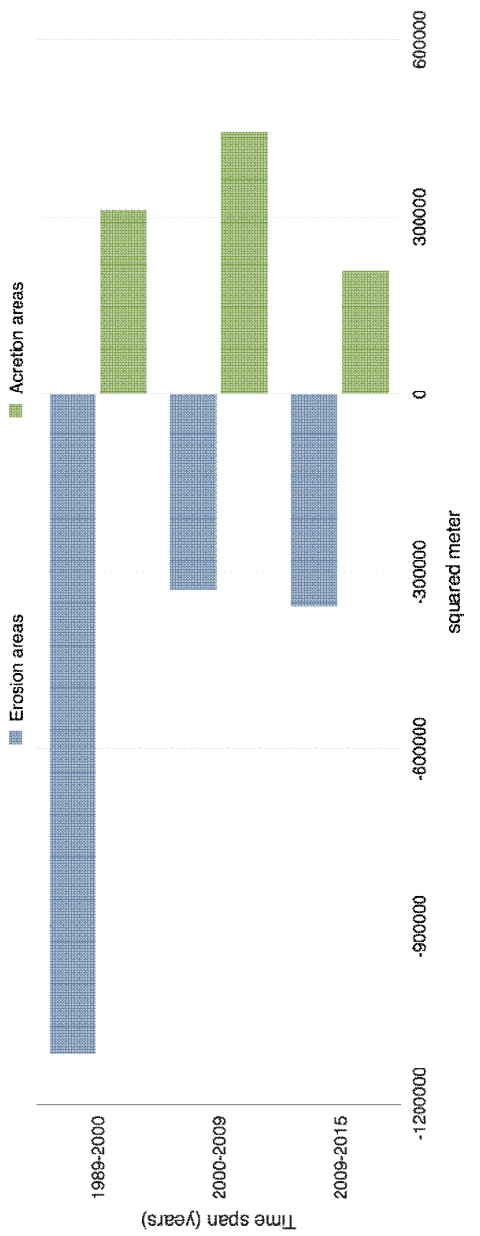

Figure 7. Beach surface changes from 1080 to 7015

\section{Conclusion}

For 25 years since 1989, Vung Tau city has witnessed a massive shoreline replacement including severe erosion and gradual accretion. The assessment has been fully identifiedthat VungTau's shoreline changes significantly over time. Overall, the shoreline of Vung Tau is characterized by a disequilibrium state of coastal morphological changes. CuaLap river mouth features all-time biggest changes withmore than 800 meter of retreating shoreline. The differences in EPR of other periods of time can be explained by human activities on construction of dike system (positive) and sand mining, industrialization (negative).Ba Ria- Vung Tau government bodies should invest on upgrading existing dike system and construction of cargo/ship terminal areas in order to make the most of jetties to deposit Cua Lap area. 


\section{Nhận dạng sự biến đổi đường bờ: phân tích dữ liệu địa không gian ở thành phố Vũng Tàu, phía Nam Việt Nam}

- Bùi Trọng Vinh

- Lý Minh Hoàng

Bộ môn Tài nguyên Trái Đất và Môi trường, Khoa Kỹ thuật Địa chất và Dầu khí, Trường Đại học Bách Khoa, ĐHQG-HCM

\section{TÓM TẮT}

Trong nhũng năm gần đây, xói lở bãi biển và bò̀ biển xảy ra ngày càng tăng khắp nơi trên thế giói. Do biến đổi khí hậu và các hoạt động của con người, nhiều bãi biển và bò̀ biển đã bị xói lơng hiêm trong ở Việt Nam, đặc biệt là Thành phố Vũng Tàu. Để hiểu và giải thích các nguyên nhân tại sao các bãi biển ở Vũng Tàu bị xói lở, tác giả đã sủ dụng công cu hệ thống thông tin địa lý (GIS) và viến thám (RS) để phân tích sư dịch chuyển bãi biển và bò̀ biển trong quá khứ và hiện tại. Kết quả phân tích cho thấy thành phố Vũng Tàu có sư thay đổi rất lón bao gồm cả xói lở và bồi tu tù năm 1989. Khu vực cưa sông Cửa Lấp làn ơ xói lở mạnh nhất với tốc độ hơn $800 \mathrm{~m}$.

Tù khoá: xói lở bãi biển, xói lở bờ biển, bồi tụ, hệ thống thông tin địa lý, viễn thám, Vũng Tàu, Cưa Lấp, cửa sông.

\section{REFERENCES}

[1]. AielloA., F. Carona, G.P, G.S (2013)Shoreline variations and coastal dynamics: A space-time data analysis of the Jonian littoral, Italy

[2]. Deguchi Ichiro,Araki S., Nakaue T., Shimizu A. and Hattori H., (2005)." Detection of shoreline by ASTER image and the difference between detected and surveyed shorelines," Civil Engineering in the Ocean, Vol.21, pp. 439444.

[3]. Le Cong Van, $\mathrm{Cu}$ Van Nguyen, TomoyaShibayama (2014)- Assessment of Vietnam coastal erosion and relevant laws and policies - Coastal disaster and climate change in Vietnam: Engineering and Planning perspective (Nguyen DanhThao)

[4]. Montgomery Carla W. (2011) Environmental Geology $9^{\text {th }}$ editionChapter 7 zone and processes

[5]. MortonRobert A. Tara L. Miller and LJM (2004) National assessment of shoreline change: Part 1- Historical shoreline changesand associated coastal land loss along the U.S Gulf of Mexico

[6]. Morton Robert A. Tara L. Miller and LJM (2005) National assessment of shoreline change: Part 2- Historical shoreline changes and associated coastal land loss along the U.S South East Atlantic Coast 
[7]. Pusty N.P., T.M.Silveria (2011)Monitoring shoreline change along Assateague Barrier Island: The first trend report, Journal of Coastal Research (JCR) Special Issue 64

[8]. Schmidt-Thome Phillip, Thi Ha Nguyen, Thanh Long Pham

JaanaJarva, KristiinaNouttimaki (2015)Climate change adaptation measures in Vietnam: Development and Implementation

[9]. Thieler, E.R., Himmelstoss, E.A., Zichichi,
J.L., and Ergul, Ayhan, (2009)- Digital Shoreline Analysis System (DSAS) version 4.0-An ArcGIS extension for calculating shoreline change: U.S. Geological Survey Open-File

[10].Tien, P.H., Cu, N.V., Cong, L.V., Hung, H.H., Huong, N.T., Sam, D.X., (2005).Researches, Forecasts and Measures to Prevention of Erosion and Landslide along the Coastline in Vietnam. State Final Report. Code KC.09.05. Institute of Geography, Hanoi. 